\title{
Association between Mothers' Characteristics, Knowledge, Attitude, and Practice and Intestinal Helminthes Infection on Children
}

\author{
Nadhira Permata Hakiki, ${ }^{1}$ Lia Faridah, ${ }^{2}$ Meita Dhamayanti, ${ }^{3}$ Dida Akhmad Gurnida ${ }^{3}$ \\ ${ }^{1}$ Faculty of Medicine, Universitas Padjadjaran, ${ }^{2}$ Departement of Microbiology \& Parasitology \\ Faculty of Medicine, Universitas Padjadjaran, ${ }^{3}$ Departement of Child Health Faculty of Medicine, \\ Universitas Padjadjaran/Dr. Hasan Sadikin General Hospital, Bandung
}

\begin{abstract}
Background: The prevalence of soil-transmitted helminthes infection in Indonesia is still high, especially in children aged 3 to 8 years old. Helminthes infection cause loss of nutrition, delay physical development, intelligence, and labor productivity and decrease immunity. Mothers' characteristics, knowledge, attitude, and practice are some of the factors that influence the occurrence of intestinal helminthes infection on children. This study was aimed to find the association between mothers' characteristics, knowledge, attitude, and practice and the occurrence of intestinal helminthes infection on children.

Methods: The study was conducted at Jatinangor Cohort's research center from August to September 2014 using cross sectional analysis. One hundred and forty five secondary data were collected using validated questionnaire that filled by mothers and results of feces on children were tested. The amount of data excluded due to incomplete was 8, the data utilized was then analyzed by Chi Square evaluation.

Results: Mothers' characteristics such as age $(P=0.611)$, education $(P=0.952)$, occupation $(P=0.876)$, income $(P=0.199)$, and knowledge $(P=0.424 ; 0 R=1.333)$, attitude $(P=0.236 ; 0 R=0.808)$, practice $(P$ $=0.333 ; \mathrm{OR}=4.625$ ) did not have a significant association with the occurrence of intestinal helminthes infection on children.

Conclusions: Characteristics, knowledge, attitude, and practice of the mothers towards the intestinal helminthes infection do not associate with the occurrence of intestinal helminthes infection on children. [AMJ.2016;3(2):248-53]
\end{abstract}

Keywords: Attitude, characteristics, intestinal helminthes infection, knowledge, practice

\section{Introduction}

Globally, more than 1 billion people are infected by soil-transmitted helminthes, especially in warm yet moist climate area. In Indonesia, the occurrence of intestinal helminthes infection is a public health problem, especially for the children with the age of elementary school student. Study showed that 60 out of 100 elementary school students in South Tapanuli ${ }^{1}$ were infected by helminthes. Study in Palu ${ }^{2}$ showed that 93 out of 180 subject infected by helminthes were elementary school students. Study in Bandung ${ }^{3}$ showed that 22 out of 142 elementary school students were infected by helminthes. Children are more often infected than adults, with the most frequent range of age from 3 to 8 years old. ${ }^{4}$

Helminthes infection causes loss of nutrition, delay physical development, level of intelligence, labor productivity and decrease in immunity system. ${ }^{4}$ Society level of healthiness are influenced by four factors. Knowledge, attitude, and practice are the most dominant influential factors on the dynamic of society's level of healthiness. ${ }^{5}$ Study showed that health status is also influenced by family, included parent's characteristics such as level of education, income, etc. ${ }^{6-8}$ According to those conceptions, mothers' characteristics, knowledge, attitude, and practice towards a certain kind of disease play its role in the occurrence of the particular disease itself. Hence, this study was conducted to discover the association between mothers' characteristics, knowledge, attitude, and practice towards the helminthes infection and the occurrence of intestinal helminthes infection on children.

Correspondence: Nadhira Permata Hakiki, Faculty of Medicine, Universitas Padjadjaran, Jalan Raya Bandung-Sumedang Km.21, Jatinangor, Sumedang, Indonesia, Phone: +62 81311260236 Email: nadhiraph@gmail.com 


\section{Methods}

The study was conducted in Jatinangor Cohort's research center from August to September 2014 using cross sectional analysis. The study have been approved by the Health Research Ethics Committee, Faculty of Medicine Universitas Padjadjaran. Population was secondary data retrieved from Jatinangor Cohort study.

Inclusive requirements were applied in the process of collecting the secondary data that were going to be used, as the data used was the complete data. Thus, according to the aforementioned requirements, the number of subject was only 137 mothers whom children aged an elementary school student in Jatinangor which included the first, second, and third grade of elementary school students (aged 6-8 years old) in two elementary schools. The amount of subject has reached the minimum sample that should be obtained.

The free variables used as the main elements of the study were mothers' characteristics, knowledge, attitude, and practice. The tied variables used as other elements of the study were the occurrence of intestinal helminthes infection on children.

The measurement technique for the data of mothers' characteristics, including age, education level, occupation, and income used for biography questionnaire. The questionnaire consisted of five choice answers. The measurement technique for the data of knowledge, attitude, and practice used validated questionnaire. Getting data of knowledge was conducted using a questionnaire containing 10 questions. Favorable questions got 1 point if it was correct and 0 points if it was incorrect, while for the

Table 1 Mothers' Characteristics

\begin{tabular}{lcc}
\hline \multicolumn{1}{c}{ Variable } & Frequency (N=137) & Percentage (\%) \\
\hline Age (years old) & 19 & 13.9 \\
$21-30$ & 72 & 52.6 \\
$31-40$ & 41 & 29.9 \\
$41-50$ & 3 & 2.2 \\
$51-60$ & 2 & 1.5 \\
61-70 & & \\
Education & 0 & 0 \\
Uneducated & 32 & 23.4 \\
Elementary school & 49 & 35.8 \\
Junior high school & 46 & 33.6 \\
Senior high school & 10 & 7.3 \\
College & & \\
Occupation & 10 & 7.3 \\
With monthly salary & 32 & 23.4 \\
Entrepreneur & 6 & 4.4 \\
Freelancer & 50 & 36.5 \\
Unemployed & 39 & 28.5 \\
Others & & \\
Monthly income (average in rupiahs) & 15 & 10.9 \\
Under 1.050.000 & 49 & 35.8 \\
1.050.001-2.000.000 & 58 & 42.3 \\
2.000.001-6.000.000 & 15 & 10.9 \\
More than 6.000.000 & & \\
\hline
\end{tabular}


unfavorable questions, those got 1 point if it is incorrect and 0 point if it is correct (Guttmann Scale) so that the highest and lowest score would be 10 and 0 point. Group of good and bad knowledge was categorized based on median. The results were considered as good if the amount of the score was higher than median and categorized as bad if the amount of the score was lower than median.

Data of attitude was acquired using a questionnaire containing 6 questions where the point would be worth 4 points if it was "highly agree", 3 points if it was "agree", 2 points if it was "disagree", and 1 point, if it was "highly disagree" (Likert Scale) so that the highest score would be 24 points and the lowest would be 6 points. Group of positive and negative attitude were categorized based on median. The results were considered as positive if the number of the score was higher than median. Those were considered as negative if the number of the score was lower than median.

Data of practice was got using a questionnaire with 6 questions where the highest and lowest score would be 120 and 29 points (Ordinal Scale). Group of good and bad practice were categorized based on median. The result was considered as a good result if the score was higher than median and considered as a bad one if the score was lower than the median.

The process of data in this study used computerized analysis. To determine whether there was an association between mothers' characteristics, knowledge, attitude, and

Table 2 Association between Mother's characteristic and the Occurrence of Helminthes Infection on Children

\begin{tabular}{|c|c|c|c|c|}
\hline \multirow{2}{*}{ Characteristic } & \multicolumn{2}{|c|}{ Helminthes Infection } & \multirow[t]{2}{*}{ Total } & \multirow[t]{2}{*}{$\mathbf{p}$} \\
\hline & Positive N (\%) & Negative N (\%) & & \\
\hline \multicolumn{5}{|l|}{ Age (years) } \\
\hline $21-30$ & $3(15.8)$ & $16(84.2)$ & 19 & $\mathrm{p}=0.611$ \\
\hline $31-40$ & $11(15.3)$ & $61(84.7)$ & 72 & \\
\hline $41-50$ & $9(22)$ & $32(88)$ & 41 & \\
\hline $51-60$ & $1(33.3)$ & $2(66.7)$ & 3 & \\
\hline $61-70$ & $1(50)$ & $1(50)$ & 2 & \\
\hline \multicolumn{5}{|l|}{ Education } \\
\hline Uneducated & 0 & 0 & 0 & $\mathrm{p}=0.952$ \\
\hline Elementary school & $5(15.7)$ & $27(84.3)$ & 32 & \\
\hline Junior high school & $10(20.4)$ & $39(79.6)$ & 49 & \\
\hline Senior high school & $8(17.4)$ & $38(82.6)$ & 46 & \\
\hline College & $2(20)$ & $8(80)$ & 10 & \\
\hline \multicolumn{5}{|l|}{ Ocupation } \\
\hline With monthly salary & $2(20)$ & $8(80)$ & 10 & $\mathrm{p}=0.876$ \\
\hline Entrepreneur & $4(12.5)$ & $28(87.5)$ & 32 & \\
\hline Freelancer & $1(16.7)$ & $5(83.3)$ & 6 & \\
\hline Unemployed & $11(22)$ & $39(78)$ & 50 & \\
\hline Others & $7(18)$ & $32(82)$ & 39 & \\
\hline \multicolumn{5}{|l|}{ Income } \\
\hline Under 1.050 .000 & $3(20)$ & $12(80)$ & 15 & $\mathrm{p}=0.199$ \\
\hline $1.050 .001-2.000 .000$ & $5(10.2)$ & $44(89.8)$ & 49 & \\
\hline $2.000 .001-6.000 .000$ & $15(25.9)$ & $43(74.1)$ & 58 & \\
\hline More than 6.000 .000 & $2(13.3)$ & 13 (86.7) & 15 & \\
\hline
\end{tabular}


practice and intestinal helminthes infection on children, Chi Square evaluation was then implemented. In the process of its interpretation, the $\mathrm{p}$ value was observed; if the $\mathrm{p}$ value is $>0.05$. The association will be significant, if the $p$ value is $<0.05$, the association will be significant.

\section{Results}

The result showed that helminthes egg was found in 25 children's feces sample. It indicated that that prevalence of helminthes infection on children in Jatinangor is $18.2 \%$.

Most of mother were in the range of 31 to 40 years old, junior high school graduated, unemployed, had average monthly income 2.000 .001 to 6.000 .000 rupiahs per month. (Table 1)

Mother's characteristics including age, education, income, and occupation were not associated with the occurrence of intestinal helminthes infection on children (Table 2).

The mean and median for the knowledge variable were 7.4 and 5.5. The highest score acquired by the subjects for the knowledge variable was 10 , while the lowest score was 3 . The mean and median for the attitude variable were 20.3 and 15 . The highest score acquired by the subjects for the attitude variable in the study was 24 , while the lowest score was 7 . The mean and median for the practice variable were 102.4 and 72.5 . The highest score acquired by the subjects for the behavior variable in the study was 121, while the lowest score was 64 . The result of analysis using the Chi Square test showed that the $\mathrm{p}$ value for the association between knowledge, attitude and practice of the mother and the helminthes infection was more than 0.05 so that the association was considered not significant.

\section{Discussion}

According to the result of the study, most of the subjects involved were mothers who were aged range from 31 to 40 years old, junior high school graduated, unemployed, and had income range from 2 to 6 million rupiahs per month. The result of analysis using Chi Square showed that the mothers' characteristics had $p$ value $>0.05$ and the association between the mothers' characteristics and the occurrence of intestinal helminthes infection on children was considered not significant.

From 18 subjects who had low level of knowledge, $4(22.2 \%)$ of them have children who have helminthes eggs in their feces. The $p$ value for the association between mothers' level of knowledge and the occurrence of helminthes infection on children was 0.424 with 1.333 odd ratio. It signified that mothers with bad knowledge concerning the helminthes infection had high risk of their children infected. It was 1.333 times bigger than the mothers who have good knowledge about the disease. According to the analysis with Chi Square, it was discovered that there were no significant association between mothers' knowledge about the infection and the occurrence of intestinal helminthes infection on children because the $\mathrm{p}$ value $>0.05$. The results of this study was not in line with the study in Amazon ${ }^{9}$ on 329 children

Table 3 Association between Mothers' Knowledge, Attitude, and Practice and the Occurrence of Helminthes Infection on Children

\begin{tabular}{lcccccc}
\hline \multirow{2}{*}{ Variable } & \multicolumn{2}{c}{ Helminthes Infection } & \multirow{2}{*}{ OR } & \multicolumn{2}{c}{ CI 95\% } & \multirow{2}{*}{ P value } \\
\cline { 2 - 3 } & Positive N (\%) & Negative N (\%) & & Min & Max & \\
\hline Knowledge & $4(22.2)$ & $14(77.8)$ & 1.333 & 0.399 & 4.458 & 0.424 \\
$\quad \begin{array}{l}\text { Bad } \\
\text { Good }\end{array}$ & $21(17.7)$ & $98(82.3)$ & & & & \\
$\begin{array}{c}\text { Attitude } \\
\quad \text { Negative }\end{array}$ & 0 & $25(100)$ & 0.808 & 0.894 & 0.983 & 0.236 \\
$\quad \begin{array}{l}\text { Positive } \\
\text { Practice }\end{array}$ & $7(6.3)$ & $105(93.7)$ & & & & \\
$\quad \begin{array}{l}\text { Bad } \\
\text { Good }\end{array}$ & $1(4)$ & $24(96)$ & 4.625 & 0.279 & 76.56 & 0.333 \\
\hline
\end{tabular}


samples which found that mothers' knowledge had negative association with the occurrence of helminthes infection on children. It was probably caused by different study location and the amount of sample.

Referring to the results of study, from 25 subjects with negative attitude towards the problem, there were no subjects whose children had helminthes eggs in their feces. The $p$ value for the association between mothers' attitude and the occurrence of helminthes infection on children was 0.236 with 0.808 odd ratio. This indicated that mothers with negative attitude towards the helminthes infection had high risk of their children infected. It was 0.808 times bigger than the mothers who had positive attitude about the disease.

As much as 25 mothers with bad practice, 1 (4\%) of them having children who was positively infected on helminthes eggs in their feces. The $p$ value for the association between mothers' practice and the occurrence of helminthes infection on children was 0.333 with 4.625 odd ratio. It signified that mothers with bad practice towards the helminthes infection had the risk of their children infected the disease 4.625 times bigger than the mothers who had good practice. Referring to the result of Chi Square evaluation, there were no significant association between mothers' practice towards the infection and the occurrence of intestinal helminthes infection on children because the $p$ value was $>0.05$.

There has not been yet similar study that discovered an association between mothers' characteristics, knowledge, attitude and practice and the actual occurrence of intestinal helminthes infection on children in West Java.

The irrelevance between mother's knowledge, attitude, and practice and the occurrence of intestinal helminthes infection on children was probably caused by the multidimensionality of the disease. In other words, the knowledge, attitude and practice factors were not the only influential factors in the occurrence of helminthes infection. There were other factors that caused the helminthes infection such as social-economy, sanitary, mother's level of education, the condition of floor in houses, and many others., ${ }^{60-14}$ In this study, it has been discovered that in socialeconomy aspect, which was measured through income, $58(42.3 \%)$ out of 137 subjects have income above the average regional payment (Upah Minimum Regional/ UMR) of Sumedang as 1.735 .470 rupiahs. From the educational aspect of the mother, 49 (35.8\%) and $46(33.6 \%)$ subjects were graduated from junior high school and senior high school. From occupational aspect, $50(36.5 \%)$ out of 137 subjects are unemployed. From all the different aspects, most of the subjects have decent educational and social-economy level, hence these factors are indeed possible to become one of the causes that situate the low prevalence level of helminthes infection in Jatinangor. The limitation of the study did not measure other factors that can influence the intestinal helminthes infection. The degree of healthiness of people is influenced by four factors, which are environment, behavior correlated with the balance of ecology, lineage influenced by the population and distribution of the residents, and health services. ${ }^{5}$ Knowledge, attitude and practical factors are only included within behavior factors that correlate with the balance of ecology, while three of other factors were not measured in this particular study.

This certain situation was not in line with the result of analysis on subjects' characteristics in this study. From this study, it was then discovered that the characteristics of the mothers including educational level and income did not have any association with the occurrence of helminthes infection on children. This was probably caused by one single factor that did not influence the occurrence of helminthes infection.

From the study, it can be concluded that there were no association between the mothers' characteristics, knowledge, attitude and practice towards the helminthes infection and the occurrence of intestinal helminthes infection on children. Further study should be conducted with wider area to represent suburban and urban area with elaborated the other factors that cause the occurrence of intestinal helminthes infection on children.

\section{References}

1. Fitri J, Saam Z, Hamidy MY. Analisis faktorfaktor risiko infeksi kecacingan murid sekolah dasar di Kecamatan Angkola Timur Kabupaten Tapanuli Selatan tahun 2012. Jurnal Ilmu Lingkungan. 2012;6(2):14661.

2. Chadijah, Sumolang PPF, Veridiana NN. Hubungan pengetahuan, perilaku, dan sanitasi lingkungan dengan angka kecacingan pada anak sekolah dasar di Kota Palu. Media Litbangkes. 2014;24(1):50-6.

3. Silitonga MM, Sudharmono U, Hutasoit M. Prevalensi kecacingan pada murid sekolah dasar negeri di Desa Cihanjuang 
Rahayu Parongpong Bandung Barat. MKB. 2009;41(2):260-4.

4. USAID's Neglected Tropical Diseases Program. Soil transmitted Helminthiasis. 2014. [Cited 2014 September 2]; Available from: https://www.neglecteddiseases. gov/target_diseases/soil_transmitted_ helminthiasis/.

5. Notoatmodjo S, editor. Promosi kesehatan teori dan aplikasi. Jakarta: Rineka Cipta; 2005.

6. Omoigberale A, Airauhi L. Aspects of the epidemiology of intestinal parasitosis (IP) in children: knowledge, practice and perceptions of mothers. Niger J Clin Pract. 2006;9(2):109-13.

7. Ferrer RL, Palmer R, Burge S. The family contribution to health status: a population-level estimate. Ann Fam Med.2005;3(2):102-8.

8. Kattula D, Sarkar R, Ajjampur SSR, Minz S, Levecke B, Muliyil J,et al. Prevalence \& risk factors for soil transmitted helminth infection among school children in South India. Indian J Med Res. 2014;139(1):7682.

9. Tanner S, Chuquimia-Choque ME, Huanca T, McDade TW, Leonard WR, Reyes-García
$\mathrm{V}$. The effects of local medicinal knowledge and hygiene on helminth infections in an Amazonian society. Soc Sci Med. 2011;72(5):701-9.

10. Strunz EC, Addiss DG, Stocks ME, Ogden S, Utzinger J, Freeman MC. Water, sanitation, hygiene, and soil-transmitted helminth infection: a systematic review and metaanalysis. PLoS Med. 2014;11(3):e1001620.

11. Huat LB, Mitra AK, Jamil NIN, Dam PC, Mohamed HJJ, Muda WAMW. Prevalence and risk factors of intestinal helminth infection among rural Malay children. J Glob Infect Dis. 2012;4(1):10-4.

12. Faridan K, Marlinae L, Al Audhah N. Faktorfaktor yang berhubungan dengan kejadian kecacingan pada siswa Sekolah Dasar Negeri Cempaka 1 Kota Banjarbaru. Buski. 2013;4(3):121-7.

13. Rahayu N,Ramdani. Faktor risikoterjadinya kecacingan di SDN Tebing Tinggi di Kabupaten Balangan Provinsi Kalimantan Selatan. Buski. 2013;4(3):150-154.

14. Andaruni, Fatimah, Simangunsong B. Gambaran faktor-faktor penyebab infeksi cacingan pada anak di SDN 01 Pasirlangu Cisarua. Students E-Journal. 2012;1(1):28-42. 